\title{
Pădurile din Ardeal și Tratatul dela Trianon*
}

\author{
P. Antonescu \\ Profesor la Școala Politechnică Regele Carol II, Inginer consilier silvic
}

Lucrarea „Pădurile și Ardeal și Tratatul de la Trianon” publicată de profesorul Petre Antonescu în 1931, (Tipografia „Bucovina”, I. E. Toronțiu, București) este o aprofundată sinteză a politicilor forestiere, adoptate de statele apărute în urma dezmembrării Imperiului Austru-Ungar. Cartea, deși structurată mai degrabă ca note călătorie decât ca demers științific, descrie experiența nemijlocită a autorului la reașezarea, pe noi baze juridice, a celei mai vechi organizații trans-naționale, apărute în Europa după Războiul Crimei: Comisia Europeană a Dunării, creată în 1856.

Prerogativele acestei organizații au fost restrânse după declanșarea celui de-al Doilea Război Mondial, devenind Administrația Dunării de Jos (1938-1940, cu sediul la București), urmând ca după război să fie reorganizată sub denumirea de Comisia Dunării, cu sediul la Budapesta. Una din recomandările Convenției privind navigația pe Dunăre, semnată la Belgrad în 1948, a fost aceea ca radioul public al țărilor riverane să difuzeze zilnic, în franceză, română și rusă, cotele apelor Dunării, probabil cea mai longevivă emisiune a postului național de radio.

În cele 151 pagini sunt descrise ultimele cinci sesiuni de lucru ale Comisiei, desfășurate în perioada 1925-1930. Structura materialelor prezentate de experții forestieri în fiecare sesiune diferă de la un an la altul și de la țară la țară, în funcție de prioritățile legislative, de inundațiile produse între timp, sau de consecințele reformei funciare din România, singura țară a cărei politică forestieră a fost marcată de o profundă reformă agrară.

Totuși, pentru a asigura funcționarea respectivei comisii, articolul cinci al regulamentului de funcționare prevedea că delegații statelor semnatare ,,vor procura Comisiunii, sub titlul de informațiuni, documentele următoare: a) un expozeu anual sumar asupra situațiuni tehnice... b) acordurile încheiate între statele interesate, cu sau fără intervenția Comisiunii, c) legile și actele reglementare relative la regimul apelor, la despăduriri, la pescării”.

Dacă ne raportăm la rigoare științifică a „expozeelor”, trebuie să recunoaștem faptul că, la vremea la care a fost scris textul, probitatea științifică era recunoscută ca atare, fără temerea unei interpretări în cheia politică: deși Uniunea Sovietică era în plină teroare stalinistă, autorul mărturisește o nedisimulată admirație pentru reprezentanții școlii ruse de pedologie care „,cei d'ânâi, au dovedit că fiecărui tip de vegetație îi corespunde un tip special de sol”. La vremea aceea nu se știa de corectitudine politică iar comunicarea era mult mai directă și, firește, mai sinceră.

Legislația forestieră era simplă și ușor de aplicat, fiind bazată pe criterii clare și unanim acceptate. Astfel, regimul silvic aplicat în Cehoslovacia se baza o dihotomie simplă, ce pornea de la un prag de 50 ha, privind micile proprietăți forestiere: astfel, în pădurile tratate în crâng simplu sau compus, dacă suprafața proprietății era sub acest prag, parchetul anual era cel mult a douăzecea parte din suprafață, iar în restul situațiilor, același parchet anual, era cel mult a treizecea parte din suprafață. La pădurile de codru regulat, pentru proprietățile de până la 50 ha suprafața parchetului anual era a șaizecea parte din proprietate, iar dincolo de prag parchetul anual scădea la a optzecea parte.

La întâlnirea din 1926, găzduită de Budapesta, delegatul Regatului Sârbilor, Croaţilor și Slovenilor a recunoscut, ca principal reglator hidrologic, așa-numitul „tapet vegetal”. Având în vedere experiența silvicultorilor francezi care, după inundațiile din 1856, au acordat o atenție sporită modului de gestionare a terenurilor în zona înaltă a bazinelor de intercepție, silvicultorii iugoslavi au interzis pășunatul, defrișarea și transformarea livezilor în culturi arabile, în bazinele superioare. Același principiu călăuzitor a fost adoptat de Austria, în Tirol și Carintia, după inundațiile catastrofale din 1882. Delegatul respectiv a atras atenția reprezentanților României asupra faptului că în bazinele de intercepție ale Timișului, Begăi și Bârzavei trebuie adoptate aceleași măsuri, pentru a împiedica propagarea unor unde de viitură în țara vecină. Ba mai mult, a propus un sistem de raportare și monitorizare a folosințelor funciare, bazat pe o serie de tabele asemănătoare actualului sistem LULUCF (land use, land use change to forestry), acompaniat de hărți la scara 1:200.000. Delegatul Regatului sârbilor, Croaților și Slovenilor, cărora li s-au adăugat și delegatul Ungariei, au solicitat date privind despăduririle (volumul extras pe specii, plus volumul rămas pe picior), reîmpăduririle, suprafețele pășunate, terenurile degradate.

"Lucrarea reproduce parțial originalul (pag. 5-28): Antonescu P., 1931. Pădurile din Ardeal și Tratatul dela Trianon. Tipografia „Bucovina”, I.E. Torouțiu, București, 151p. 
În Ungaria se aplica în continuare o lege adoptată în 1879, ce obliga toți marii deținători de păduri să recolteze lemn pe baza unui amenajament silvic, prin care se urmărea raportul susținut (continuitatea recoltelor). În pădurile private, cu excepția celor cu rol de fixare a nisipurilor, era posibilă chiar și defrișarea, motiv pentru care mare parte din aceste păduri au fost tăiate în perioada războiului. Petru a stopa despăduririle ce luaseră amploare în perioada războiului, în 1918, guvernul ungar a emis o ordonanță potrivit căreia nicio pădurea nu mai putea fi exploatată fără o autorizare specială emisă de serviciul forestier. În Transilvania, această ordonanță a funcționat până în 1923, când codul silvic aplicat în vechiul regat încă din 1910 a fost extins în întreaga țară.

Interesant este faptul că respectivul cod prevedea o garanție pentru regenerarea pădurii, depusă în conul Ministerului Agriculturii: 100 lei/ha, până în 1920, respectiv 3000-4000 lei/ha, după 1920, la care se adaugă și obligația proprietarului pădurii respective de a avea propria-i pepinieră. Dacă pădurile erau exploatate fără amenajament sau regulament de exploatare, amenda era undeva între 3000 și 5000 lei/ha. Potrivit aceleași legi, defrișarea era complet interzisă, exceptând situațiile în care pădurea era transformată în livadă sau când pădurea, situată în zona de câmpie, avea o suprafață mai mică de 25 ha, sau în cazul unei regularizări a folosinței forestiere, prin împădurirea unei enclave, situație în care o suprafață echivalentă ca mărime putea fi defrișată. Chiar și în aceste condiții, defrișarea era posibilă după ce puieții instalați în fosta enclavă vor fi depășit vârsta de trei ani iar starea de masiv va fi fost închisă.

Unul din laitmotivele textelor referitoare la politica forestieră românească din perioada interbelică este „legiferarea” defrișărilor prin reforma funciară din 1923. Poate efectele ar fi fost și mai grave în ceea ce privește defrișarea pădurilor, dacă măsurile luate de Casa Pădurilor în ceea ce privește împădurirea nu ar fi fost coerente și pragmatice: pădurarii (5446 la număr, în 1923) erau obligați să înființeze pepiniere cantonale, să planteze cel puțin zece mii de puieți anual, iar superiorii acestora să le acorde asistența tehnică necesară reușitei definitive, pe lângă atribuțiile de control.

Principala concluzie la care ajunge cititorul este că țările riverane Dunării deveniseră laboratorul pe care se aplicau, la scară mare, cele mai potrivite soluții de gestionare a pădurilor, așa cum erau ele promovate de Școala Națională de ape și păduri de la Nancy. Ceea ce nu era deloc rău, într-o Europă ce-și căuta drumul spre pace, printre altele, și prin armonizarea politicilor forestiere și diminuarea pagubelor produse de inundațiile ce apar periodic în bazinul Dunării.

\section{Marian Drăgoi}

Universitatea „Ștefan cel Mare” din Suceava, Facultatea de Silvicultură

\section{Comisiunea regimului apelor Dunării}

$\mathrm{Cu}$ ocaziunea negocierilor de pace dela Neuilly, cari au avut loc în lunile Ianuarie, Februarie şi Martie 1920, delegații guvernului Ungar au cerut şi puterile aliate şi asociate au aprobat, ca la Capitolul III referitor la regimul apelor din Tratatul dela Trianon, încheiat la 4 Iunie 1920, să se adaoge articolele 292 şi 293, a căror cuprindere este următoarea:

\section{ARTICOLUL 292}

„Afară de dispozițiuni contrare când, în urma trasării unei noui fruntarii, regimul apelor (canaluri, inundațiuni, irigațiuni, drenaj sau lucrări analoage) dintr'un Stat, depinde de lucrări executate pe teritoriul unui alt Stat, sau când se întrebuințează pe teritoriul unui Stat, $\hat{i n}$ virtutea unor uzuri anterioare răsboiului, ape sau energii hidraulice născute pe teritoriul unui alt Stat, trebuie să se stabilească o ințelegere intre Statele interesate, aşa încât să se păstreze interesele şi drepturile dobândite de fiecare din ele.
Afară de dispoziții contrare, când se întrebuințează de către un Stat pentru nevoi municipale sau domestice, electricitate sau apă, cari in urma traseului nouei frontiere sunt sau se găsesc pe teritoriul unui alt Stat, trebuie să se stabilească o ințelegere intre Statele interesate spre a apăra interesele şi drepturile dobândite de fiecare din ele. Până la înfăptuirea acestei ințelegeri stațiunile electrice şi instalațiunile cari furnizează apa, vor fi ținute să continue furnitura pe baze corespunzătoare condițiunilor şi contractelor in vigoare la 3 Noembrie 1918.

In lipsă de înțelegere, în cazul unuia sau celuilalt din aliniatele cari preced şi sub rezerva stipulațiunilor articolului 293, se va hotărî de un arbitru desemnat de Consiliul Societății Națiunilor.

\section{ARTICOLUL 293}

„In vederea aplicării art. 292, pe teritoriul fostului regat al Ungariei formând basinul Dunării, afară de basinul Oltului, precum şi pentru executarea atribuțiunilor prevăzute mai 
jos, se institue, in interesul comun al Statului având suveranitatea asupra ziselor teritorii, o Comisiune tehnică, permanentă a regimului apelor, cuprinzând un reprezentant al fiecăruia din Statele interesate din punct de vedere al teritoriilor şi un prezident numit de către Consiliul Societății Națiunilor.

„Această Comisiune va trebui să întocmească încheierea, supraveghierea şi în caz de urgență, să asigure, executarea înțelegerilor prevăzute la art. 292; ea va trebui să menţie şi să îmbunătățească, în special în ceeace privește împădurirea şi despădurirea, unitatea regimului apelor, precum şi serviciile, relative la acestea, ca serviciul hidrometric şi de anunțarea creșterilor de apă. Ea va proceda la studierea chestiunilor conexe navigațiunei, exceptând pe acelea cari ar fi de resortul Comisiunii de navigațiune competentă pentru Dunărea de jos, pentru care va trebui să înștiințeze, zisa Comisiune şi va ține seamă mai ales de interesul pescăriilor. In afară de aceasta Comisiunea va întreprinde orice lucrări sau studii şi va creia orice servicii, cari $i$-ar fi incredințate prin înțelegerea unanimă a Statelor interesate. Comisiunea regimului apelor va trebui să se intrunească într'un termen de 3 luni după intrarea în vigoare; ea va elabora regulamentul relativ la atribuțiunile sale şi la funcționarea sa, regulament care va fi supus aprobării Statelor interesate.

Toate neînțelegerile cari se vor ridica asupra chestiunilor cari fac obiectul prezentului articol, vor fi regulate după cum va decide Societatea Națiunilor".

Regulamentul, despre care se face mențiune Ia art. 293 aliniatul 3, a fost întocmit şi aprobat de toate Statele interesate inclusiv președintele numit de Consiliul Societăţii Naţiunilor.

Acest regulament conține 21 articole şi un aşa zis protocol de încheiere, prin care se explică, articolul 3, articolul 5 alin. a şi articolul 17.

Prin articolul 3 relativ la atribuțiunile Comisiunei se reproduce întocmai dispoziţiunile art. 293 alin. 2 din Tratatul dela Trianon, iar prin protocolul de încheiere cu privire Ia articolul 3 se spune:

„Adoptând regulamentul relativ la atribuţiunile şi la funcţionarea Comisiunei regimului apelor Dunării, membrii semnați ai zisei Comisiuni au convenit asupra celor ce urmează:

\section{Ad. ARTICOLUL 3}

„Prin despădurire şi reîmpădurire se înțeleg numai operațiunile cari pot provoca o modificare a unității regimului apelor".

Cuvântul ,despădurire” nu vizează tăerile de păduri, cari sunt făcute într'o exploataţiune normală şi regulată a vinei păduri.

Spre a nu se da loc la discuţiuni asupra interpretării cuvintelor ,exploataţiune normală şi regulată", ar fi fost de sigur mai preferabil să se fi admis următoarea redacţiune:

„Cuvântul „despădurire” nu se referă la tăierile de păduri, cari sunt făcute pe baza unui amenajament aprobat de ministerul respectiv".

In adevăr, scopul ori cărui amenajament este tocmai ca în urma unui studiu amănunţit al circumstanţelor fisice şi economice ale pădurii, să se găsească mijlocul, ca într'un timp mai mult sau mai puţin îndelungat să se ajungă la o exploataţiune, în care posibilitatea anuală să reprezinte creșterea efectivă a pădurii normale. In articolul 5 din regulamentul sau statutul Comisiunei regimului apelor Dunării se prevede: „Delegații vor procura Comisiunii sub titlu de informațiuni documentele următoare:

a) Un expozeu anual sumar asupra situațiunii technice a basinului Dunării, afară de cel al Oltului, precum şi în mod general asupra lucrărilor executate sau proiectate de fiecare stat putând exercita în mod practic, o influență asupra regimului apelor dintr'un Stat vecin.

b) Acordurile incheiate intre Statele interesate, cu sau fără intervențiunea Comisiunii, conform stipulaţiunilor art. 292 ale Tratatului dela Trianon.

c) Legile şi actele reglementare relative la regimul apelor, la despădurire, la pescării”.

Iar în protocolul de încheiere:

„Este înțeles că expozeul, despre care se 
tratează la alin. a al articolului 5, trebue să dea toate indicațiunile utile, cari se rapoartă la unitatea regimului apelor şi că expresiunea ,lucrări” se rapoartă la toate lucrările de orice natură ar fi, chiar acelea cari n'au caracterul de lucrări hidraulice, dar cari sunt de natură a exercita în mod practic o influență asupra regimului apelor dintr'un Stat vecin”. Rezultă, aşa-dar, că delegațiunea României, ca şi celelalte delegaţiuni de altminteri, este obligată de a prezinta în fiecare an o expunere asupra lucrărilor forestiere executate sau propuse a se executa în anul viitor.

\section{Necesitatea unui specialist forestier în delegați- unea română}

D-1 inginer inspector general Gh. Popescu, delegatul României, neputând părăsi țara în zilele fixate pentru sesiunea a VIII-a a Comisiunii regimului apelor Dunării (C. R. E. D.) ținută în anul 1925 la Merano (Italia), a fost însărcinat de a-1 suplini d-1 inginer inspector general I. Vardala, Directorul general al porturilor. In această sesiune fiind la ordinea zilei şi chestiunea ,despăduriri şi împăduriri” d-sa s'a prezintat la Ministerul Domeniilor, cerând a se trimite în Comisiune şi un expert technic forestier.

Ministrul de pe atunci, Al. Constantinescu, în urma recomandațiunii d-lui $C$. Opran, fostul administrator al Casei Pădurilor astăzi desființată, mi-a făcut onoarea de a-mi încredința această însărcinare.

Numirea mea fiind făcută însă numai cu câteva zile înainte de deschiderea sesiunei, în timpul drumului spre Merano, după ce am studiat regulamentul relativ la atribuţiunile Comisiunei, am ţinut să iniţiez pe d-1 Vardala cu oarecari termeni technici silvici, cu diferenţa între un regim şi un tratament, cu chestiunile privitoare la regenerări naturale şi artificiale, la împădurirea terenurilor degradate, la amenajarea pădurilor, în liniamente generale bine înţeles; i-am explicat ce este o pădure normală şi modul cum se poate ajunge la o asemenea 196 stare, ce este o pădure de protecţie etc.

Spre a-1 edifica asupra importanței ce se dă aiurea conservării şi exploatării raţionale a pădurilor, i-am dat să citească comunicarea prezintată la congresul internaţional de agricultură ţinut în anul 1913 la Gand (Belgia) de conservatorul de ape şi păduri din Franţa „Pardé” asupra „Protecțiunii pădurilor; măsuri legislative şi financiare de preconizat", precum şi darea de seamă a raportorului general „Lafosse” purtând titlul: „Cari sunt măsurile legislative şi financiare de luat pentru a se împedeca exploatarea abuzivă a pădurilor".

Când trenul traversa o pădure oarecare, era un bun prilej pentru mine de a-i arăta, cum se prezintă masivele tratate în crâng simplu, în crâng compus, sau în codru plin, cum se poate deosebi un arbore provenit din sămânță de cel din lăstar, ce este o pepinieră şi la ce servește ea, ce rol are salcâmul în împădurirea nisipurilor mișcătoare, care este succesiunea în altitudine a speciilor forestiere; iar când am trecut prin împrejurimele Triestului, unde pe mii de hectare nu se zărește decât stânca goală, sau acoperită cu rari tufe de arbuști, i-am vorbit de efectul funest al despăduririlor, precum şi de dificultățile enorme cu cari a avut să lupte administraţia forestieră spre a instala, pe ici şi colea, câteva boschete de pin austriac etc., când această regiune aparținea Austriei.

Pe zi ce trecea, îmi dam seama de facilitatea cu care d-sa se familiariza cu chestiunile technice forestiere, cele mai subtile chiar.

I-am explicat, în același timp, economia codului nostru silvic din 1910, cu modificările sale din 1920, în ce privește obligațiunile proprietarilor pădurilor particulare supuse regimului silvic, deosebirea ce face legea între un amenajament şi un regulament de exploatare, precum şi dispoziţiunile legale cu privire la exercitarea pășunatului în păduri, cazurile când se poate permite defrișarea etc., etc.

D-1 inginer inspector general Vardala a luat asemenea cunoștință despre cuprinsul legei de expropriere şi aceea de crearea de izlazuri comunale în Transilvania, Banat, Crişana şi Maramureș. 
Luând cu mine un exemplar din colecțiunea legilor forestiere ungare din 1879 şi 1898, traduse în limba franceză, le-am studiat împreună.

Ajungând la Merano mi-am procurat protocoalele (procesele verbale) despre şedinţele din sesiunea a VII-a, ținută la Bled (Serbia) în anul 1924, când pentru prima oară şi anume în ședința dela 29 Septembrie, s'a vorbit despre influenţa pădurilor asupra regimului apelor. Unii dintre delegați au susținut atunci, că enormele masse de aluviuni ce se depun la gurile Dunării în cantitate astăzi de aproape de 10 ori mai mult (2.500.000 tone) comparativ cu ceeace se draga înainte de răsboiu (250.000 tone), se datoresc despăduririlor din unele regiuni ale basinului Dunării, pe când alţii au combătut această părere. După aceştia din urmă, depunerile în chestiune trebuie atribuite la o mulţime de alţi factori ca: mărirea debitului braţului Sulina, schimbarea curenţilor mării, atât în ce priveşte forţa cât şi direcţiunea lor, furtunele cari pot avea o influenţă considerabilă asupra canalului săpat într'un teren nisipos şi protejat printr'o radă deschisă şi puţin profundă cum este aceea de la Sulina, malurile Dunării fiind expuse pe o lungime de peste $1500 \mathrm{~km}$ eroziunei apelor, etc.

\section{A VIII-a sesiune dela Merano}

A VIII-a sesiune a Comisiunei regimului apelor Dunării s'a deschis în Merano la 1 Aprilie 1925, ora 16 şi 30 minute în sala ,Kurhaus” în prezența d-lui Carlo Rossetti, președintele Comisiunei, a d-lui marchiz A. di Lungarini, sub prefect, a d-lui Max Markart, comisarul orașului Merano, a d-lui Buckeisen, delegatul Austriei, a d-lui Dietrich de Sachsenfels, asistat de d-nii Vicziàn şi de Pottere, a d-lui I. Vardala, delegatul României, asistat de d-1 profesor $P$. Antonescu; a d-lui Vilfan, delegatul Regatului Sârbilor, Croaţilor şi Slovenilor asistat de d-l Mirkov; a d-lui Mueller, delegatul Cehoslovaciei, asistat de d-nii Horak şi Smetana.

Marchizul di Lungarini în numele guvernu- lui italian își exprimă mulțumirea, că Comisiunea a ales orașul Merano pentru ținerea ședințelor sale, unde speră că lucrările vor da cele mai bune rezultate. Delegații pot să fie siguri că vor găsi la Merano primirea cea mai amicală.

D-1 Markart urează bun venit membrilor Comisiunii în orașul cu cele mai bune tradițiuni de ospitalitate, mai cu seamă în luna Aprilie când el este plin de vizitatori străini. Delegații vor avea ocaziunea să aprecieze şi încântătoarele sale împrejurimi.

Președintele, în numele Comisiunii, mulțumește d-lui sub prefect şi comisarului orașului pentru frumoasele cuvinte exprimate.

Domnia-sa citeşte, după aceasta, telegrama primită din partea şefului guvernului italian S. E. BENITO MUSSOLINI:

„Nel momento in cui apresi ottava sessione Commissione Regime delte Acque Danubio prego $S$. V. presentare Delegaţi convenuti mio cordiali benvenuto ed auguri o che lavori sessione abbianoipiù proficui risultati". Mussoli$n i$.

D-1 suprefect şi comisarul oraşului retrăgându-se, şedinţa continuă stabilindu-se ordinea lucrărilor pentru orele de dimineaţă, esperţii putându-se reuni şi după prânz.

Președintele dădu apoi cetire adresei No. 16975 din 27 Martie 1925 a Ministerului nostru al Afacerilor Străine, prin care îi face cunoscut, că pentru sesiunea a VIII-a a Comisiunei este delegat d-1 inginer inspector general Vardala, delegatul permanent, d-l inginer inspector general Gh. Popescu, neputând părăsi Bucureştii la data de 1 Aprilie curent şi că d-1 Vardala va fi asistat de d-1 profesor Petre Antonescu.

Şedinţa dela 1 Aprilie s'a ridicat la ora 17 şi 45 minute.

Chestiunea „despăduririi şi reîmpăduririi” a venit la ordinea zilei în zilele de 4 şi 6 Aprilie. In prima zi, 4 Aprilie, s'a citit şi discutat asupra expozeurilor sau rapoartelor forestiere prezintate de delegaţiunile ungare şi cehoslovace, iar la 6 Aprilie asupra celui al delegaţiunii României. 
Raportul asupra situațiunei forestiere din Ungaria

Asupra expozeului însoțit de un memoriu al delegaţiunei ungare fiind foarte voluminos, ne mulţumim a insista asupra părţilor sale esenţiale.

După o scurtă introducţiune asupra chestiunei „,despăduririi şi împăduririi”, considerată în expozeul în chestiune ca fiind foarte complexă, se precizează că din vastul teritoriu, care intră în sfera de activitate a Comisiunii regimului apelor Dunării, nu se va ocupa decât de regiunile şi perimetrele situate în imediata apropiere a şesului Ungariei.

Prin regiune se înţelege basinul unui râu, delimitat în mod natural prin liniile de despărţire a apelor, iar prin perimetru o sub diviziune a regiunei reprezintând basinul afluentului unui râu şi el determinat prin linii naturale.

Numărul regiunilor, astfel după cum le-a figurat delegaţiunea ungară pe harta anexată la expozeul său, este de 28 , însemnate cu numere romane dela I-XXVIII, multe dintr'ânsele fiind pe teritoriul român, unde reprezintă o fâşie de circa $100 \mathrm{~km}$ lăţime socotită dela actuala frontieră a Ungariei.

\section{a) Expozeul}

După studiul amănunţit al formaţiunii geologice a teritoriului vechiului Regat al Ungariei, a petrografiei şi a naturii rocelor ce-l constitue, se arată, după renumitul agrogeolog ungar $P$. Treitz, ce se înţelege prin sol forestier şi modul cum s'a format el.

Solul, după autorul expozeului, este partea superioară a crustei descompuse a rocelor, care venind în contact cu aerul devine, grație existenței microorganismelor, sediul diverselor funcțiuni vitale şi prin urmare propriu pentru creşterea plantelor de o organizaţie superioară. Solul nu depinde însă exclusiv de baza mineralogică, după cum se credea mai înainte, de oarece limitele ţinuturilor cu un acelaşi tip de sol coincide, în general, cu cele ale zonelor sau regiunilor climaterice.

Meritul de a fi descoperit distribuţiunea zo198 nală a solurilor revine învăţaţilor ruşi, cari, cei d'ântâi, au dovedit că fiecărui tip de vegetaţie îi corespunde un tip special de sol, dar cel care a aflat cauzele acestui fapt a fost Treitz, care se exprimă astfel:

„Am avut norocul de a mă putea familiariza cu lucrările învăţaţilor ruşi în Rusia chiar. Călătoriile mele în această țară, precum şi în România, mi-a întărit convingerea, că agentul cel mai important al transformării solului este forma vagetaţiunii originale. Dar când am voit să aplic acest principiu la solurile patriei mele şi a le clasifica pe această bază, am încercat mai multe eşecuri, astfel că îmi păru imposibil de a-mi îndeplini scopul. Relieful Ungariei este unul dintre cele mai variate, iar climatul său diferă dintr'un loc într'altul. Pe întinderi relativ mici, prin urmare, găsim soluri foarte diferite, situate unele lângă altele, atât în regiunea de câmpie, cât şi pe coastele munților.

$\mathrm{Cu}$ cât înaintam în cercetările mele, cu atât mă încredinţam, că în această chestiune se află ascuns un factor necunoscut, ale cărui efecte le simţeam pretutindeni şi îi vedeam urmele, dar mi se ascundea adevărata sa natură. Fără noi studii în regiunile muntoase din alte părţi decât în patria mea mă îndoiesc, însă, că aşi fi ajuns la soluţionarea problemei. Numai acolo găsii cuvântul enigmei. Acest cuvânt este simplu şi comun: este pulberea, praful, care se depune neîncetat pe sol şi care, în măsura cantităţii sale, determină calitatea solului. Dacă nu ar fi pulberea pentru a înlocui sărurile nutritive, pe cari ploile tind în totdeauna de a le duce din regiunea rădăcinelor în subsol, orice sol şi oricare ar fi forma sa de vegetaţie ar fi îndată spălat de apa acidulată, ar deveni acid şi prin urmare impropriu pentru producţiunea plantelor utile.

Această pulbere provine de pe teritoriile uscate, aride sau nisipoase, ce se află pe fiecare continent, unde solul fiind bogat în săruri este prefăcut în praf prin acţiunea eoliană şi transportat prin vârtejurile vijeliilor din deserturi în mare cantitate în regiunile înalte ale atmosferii, de unde curenţii de aer îl duc în diferitele părţi ale globului.

In Ungaria praful în chestiune provine din 
solul țării chiar, dar mai cu seamă din regiunile cu terenuri nisipoase şi alcaline dintre Dunăre şi Tisa, precum şi din părţile unde, după ce se strânge recoltele, pământul se usucă îndată".

Examinează, după aceasta, cazul hipotetic, când suprafaţa solului este acoperită de o pădure virgină: „La adăpostul acestei formaţiuni vegetale prin căderea frunzelor şi a altor rămăşiţe organice se formează humusul, substanţă poroasă şi care poate, ca un burete, să absoarbă multă apă. Aşa fiind, solul nici odată nu se usucă, dar prin procesul chimic al formaţiunii humusului, acesta este lipsit din ce în ce mai mult de aer şi înlocuit de acidul carbonic, care alcătueşte o pătură despărţitoare între sol şi oxigenul din atmosferă. Apa de ploaie trecând peste acest strat îşi pierde oxigenul absorbit din aer, se încarcă cu acid carbonic şi disolvă tot ce poate. $\mathrm{Cu}$ modul acesta rezultă o soluţiune salină, care ajungând în solul mai mult sau mai puţin acid, acţionează pe cale chimică asupra particulelor sale minerale. Stratul aflător imediat sub humus este cel d'ântâi atins şi discompus, afară însă de nisipul quarţos. Acest orizont de spălare este foarte sărac în materie humică".

Explică apoi acţiunea rădăcinelor asupra orizontului de concentrațiune sau de acumulaţiune, pe care, în timpurile secetoase, îl înavuţeşte cu materii în soluţiune având o coloare mai închisă ca cel de spălare din cauza ferului şi a materiilor organice. Limita superioară a orizontului de concentrație se confundă încetul cu încetul cu cel de spălare, iar la partea sa de jos se află orizontul rocei mume sau pământul mineral, care, prin activitatea vegetaţiei arborilor, a contribuit la formarea celor 2 strate superioare cu ajutorul agentului special, care este apa. Faptul positiv este, că solul păduros se sărăceşte în substanţe nutritive prin faptul vegetaţiei. Aşa fiind se naşte întrebarea, de unde îşi procură pădurea previziunile necesare? Din apa de ploi nu, şi nici din solul spălat de către apa acidulată, ori din roca mumă pe care rădăcinele o străbat în căutarea lor după apă. Răspunsul nu poate fi, decât că există un alt element străin independent şi de pădure şi de solul forestier. Acesta este pulberea, praful, care procură în mod continuu mineralele şi sărurile, cari înlocuiesc pe cele consumate de arbori, garantându-se astfel existenţa pădurilor.

In capitolul „pădurea" din expozeu, ni se spune: că din cele 7.392.000 hectare, ce poseda vechea Ungarie, n'a mai rămas astăzi decât 1.253.000 hectare, în teritoriul României trecând 3.792.927 ha, iar în stăpânirea Cehoslovaciei 2.118.433 ha, că distribuţiunea speciilor este influenţată de altitudine în primul rând, după care urmează clima şi cantitatea anuală a precipitaţiunilor atmosferice, iar nici decum de natura rocelor.

In ce priveşte solul, el depinde de felul speciilor ce constituie pădurea. Astfel în pădurile de reşinoase, ai căror lujeri conţin mai multe soiuri de acizi, acidul formic mai cu seamă, humusul lor posedă cel mai mare grad de aciditate, el se prezintă altfel în pădurile de stejar şi altfel în cele de fag, ale căror frunze conţin multă calce.

In capitolul „torentul”, se vorbeşte despre apa de înbibaţiune şi cea de scurgere provenită din precipitaţii atmosferice, arătând că efectul imbibaţiunii devine periculos, dacă solul este atât de săturat de apă, încât apele dintr'o altă precipitaţiune nu mai poate fi primită, ci este respinsă sau curge în vale dând naştere marilor creşteri de apă, după cum se întâmplă cu solurile impermeabile sau neîmpădurite.

Se tratează apoi despre acţiunea „omului” asupra pădurii, despre schimbarea climei datorită uscăciunii din cauza despăduririlor şi regulării cursurilor de apă precum şi a drenărilor, despre legislațiunea ungară cu începere din mijlocul secolului al XVI-lea, când ar fi existat deja un regulament forestier, despre cea din anul 1770, când reglementul obligator din timpul Măriei Tereza era în fiinţă, despre legislaţia din 1807, 1812, despre legea aflată şi astăzi în vigoare din 1879 complectată însă în 1885 prin ,legea asupra regimului apelor”, iar în 1894 prin ,legea asupra agriculturii şi poliției câmpului" referitoare la păşunatul în terenurile torenţiale expuse eroziunilor, precum şi despre legea din 1898 pe baza căreia sunt 
administrate de Stat pădurile comunale, terenurile improductive şi se reglementează gestiunea pădurilor şi a pământurilor sterile aflate în indiviziune.

Ni se face asemenea cunoscut conţinutul ordonanţei guvernamentale cu No. 3296 din luna Iulie 1898, care prevede restricțiuni în exploatarea pădurilor fără amenajamente aprobate de autorităţile forestiere.

Prin legea din 1894 şi cea din anul 1913 relative la păşunatul în pădurile aflate în devălmăşie se prescrie, că devizarea lor nu se poate face decât în urma aprobării Ministerului, iar proprietarii păşunelor indivize sunt ținuți a-şi întocmi în fiecare an un budget prevăzând lucrările de amelioraţiune şi de întreținere, buget care trebuie să fie aprobat de autorităţile administrative. Statul ungar a încurajat, afară de aceasta, exploatarea rațională şi ameliorarea păşunilor îndevălmăşie prin crearea de comisariate, la cari erau atașați ,măieștrii de pășune" cu însărcinarea de a da sfaturi şi directive pentru utilizarea economică a păşunilor şi de a contribui, dimpreună cu funcționarii comisariatelor, la modul de aplicare a dispoziţiunilor luate de autorități.

Expozeul în chestiune se termină prin următoarele două propuneri :

$\left.1^{\circ}\right)$ A se aplica în regiunile delimitate pe hartă (I-XXVIII) măsuri conforme cu dispoziţiunile vechilor legi ungare. Dacă totuşi oare cari State prin legislațiunea lor modernă prevăd măsuri mai severe ca cele ce conțineau legile ungare, noi le vom aprecia, mai cu seamă dacă le este inerentă forţa executivă, care garantează eficacitatea lor.

$2^{\circ}$ ) Să se țină o evidență pentru fiecare din cele 28 regiuni delimitate şi prezintate Comisiunii. $\mathrm{Cu}$ ajutorul acestor evidențe a regiunilor, cari vor forma parte integrantă din expozeurile anuale de prezintat în conformitate cu art. 5 din statutul nostru, Comisiunea va putea întotdeauna cunoaște adevărata stare de lucruri.

Delegaţiunea Ungară a prezintat cu această ocaziune şi tablourile cu suprafețele terenurilor degradate de pe teritoriile Statelor succesorale.

\section{b) Memoriul}

In memoriul asupra consecințelor ce poate avea despăduririle în Ungaria, se arată influenţa ce exercită asupra factorilor climaterici marile complexe de păduri, influenţă care se simte până la mari distanțe; că temperatura aerului este mai mică în pădure ca în afară; că pădurea mărește umiditatea relativă a aerului şi contribue la sporirea şi frecuenţa apelor de ploi, iar înrâurirea mecanică a pădurilor se evidențiază prin rezistența lor contra vânturilor.

Aşa fiind, o despădurire eventuală ar ameninţa şi mai mult starea de uscăciune a climatului Ungariei, ceea ce ar fi catastrofal pentru această țară agricolă. Acţiunea salutară a pădurii este incontestabilă, ea reprezintă marele rezervoriu natural şi regulatorul important al debitului râurilor. Dacă se taie o pădure, solul este lipsit de suprafaţa sa poroasă, care îl face capabil de a reține apa. După o ploaie cantitatea de apă, care curge pe un teren gol, este de 30 şi chiar de 50 ori mai mare ca pe unul despădurit. Prin despăduriri trebuie să ne aşteptăm, ca mari suprafețe cultivate să devină aride şi aceasta nu numai pe terenurile despădurite, dar şi pe acele situate mai la vale. Influenţa dezastroasă a deselor variațiuni de nivel al râurilor se exercitează în mod defavorabil mai cu seamă asupra navigațiunii. In marele șes al Ungariei lipsit de apă, nivelul apei din puțuri se va coborî şi mai mult, circumstanţă care, în caz de despădurire, desavantajele sanitare observate, numai în mod excepțional până acum, ar deveni permanente, ceeace ar avea o înrâurire pernicioasă asupra mortalității copiilor mai cu seamă.

Preşedintele mulțumi delegatului Ungariei pentru interesantul său expozeu, care a adus în discuțiune o notă de înaltă valoare științifică.

Delegatul României declără, că a apreciat expozeul în chestiune şi ia notă cu plăcere de faptul, că s'a circumscris zonele ce interesează Ungaria; ne având însă instrucțiuni precise din partea guvernului său nu poate aproba propu- 
nerile făcute, decât sub rezerva de a aprofunda ulterior chestiunea.

Delegatul Cehoslovaciei fu de aceiaşi părere ca delegatul României, a mai adăogat însă, că întru cât priveşte influenţa oarecăror rîuri din țara sa asupra regimului apelor din Ungaria se referă la expozeul său din anul acesta.

\section{Raportul forestier al delegației cehoslovace}

Suprafaţa pădurilor din Slovacia şi Rusia Subcarpatică, ce interesează Comisiunea, după statistica din 1920 este următoarea:

$$
\begin{aligned}
& \text { In Slovacia sunt . . . } 1.658 .635 \text { ha } \\
& \text { „Rusia Subcarpatică , . . . 635.367 , } \\
& \text { Total } \\
& 2.294 .002 \text { ha }
\end{aligned}
$$

După constatările făcute în părțile superioare din regiunile muntoase, în judeţul Maramureș mai cu seamă, există mari suprafeţe neîmpădurite, destinate în mare parte pentru păşunatul vitelor, dar ele nu sunt de origină recentă, de oarece se poate afirma cu siguranță, că cel puţin cu un secol înainte suprafețele lor erau tot aşa de mari ca şi astăzi. Sub vechiul regim pădurile situate în basinul Dunării şi al Tisei, afară de cele ale Statului, nu erau totdeauna exploatate după principiile unei economii forestiere raţionale.

Dispoziţiunile art. 17 din legea Ungară XXXI din 1879, privitoare la pădurile cari nu pot fi exploatate decât pe bază de amenajament, precum şi legea din 1898, referitoare la exploatarea pădurilor aparținând comunelor şi composesoratelor administrate de Stat precum şi la organizarea serviciului de pază şi de gestiune, sunt şi astăzi în vigoare în Slovacia şi Rusia subcarpatică.

Competința organelor silvice ale Statului prin legea No. 82 din. 17 Decembrie 1918 relativ la protecția pădurilor, care poate fi considerată ca cea mai riguroasă lege din Europa, a fost lărgită.

Prin această lege se prevede:

Că proprietarii, cari îşi exploatează pădurile lor pe bază de amenajamente aprobate, sunt datori a se conforma prescripțiunilor lor, întru cât nu contravin dispozițiunilor prevăzute mai jos.

Că este interzis de a se exploata pădurile de codru la o vârsta mai mică de 60 ani, iar cele de crâng simplu sau compus dacă sunt mai tinere de 20 ani.

In pădurile de codru, a căror suprafață este mai mică de 50 hectare, nu se poate tăia anual decât a 60-a parte dintr'însele, iar în cele mai mari de 50 hectare decât a 80 -a parte din întinderea totală aparținând unui proprietar.

In pădurile tratate în crâng simplu şi compus, având o suprafață mai mică de 50 hectare, nu se poate tăia anual decât a 20 -a parte, iar în cele mai mari de 50 hectare decât a 30 -a parte din întinderea păduroasă ce aparține unui singur proprietar.

Graţie acestor dispoziţiuni s'a putut împedeca devastarea pădurilor după răsboiu amenințate de împrejurările economice şi politice de pe atunci. Afară de aceasta, guvernul cehoslovac nu numai, că a limitat exploatările, dar întrebuințează sume considerabile pentru reîmpădurirea în Rusia subcarpatică a vastelor suprafețe neregenerate moștenite dela vechiul regim, în care scop s'a creiat o mulţime de pepiniere.

Pentru pădurile particulare, ale composesoratelor, ale comunelor şi alte păduri publice, se ţin la curent registrele de suprafaţa, exactă a tăierilor aprobate şi împădurite în termenul prevăzut de lege sub controlul autorităţilor forestiere ale Statului. Cei cari au exploatat în mod exagerat pădurile, de regulă nu cetăţeni cehoslovaci, au fost daţi judecăţii.

Spre a se asigura o existenţă modestă populaţiunii dela munte şi a nu o sili să emigreze din cauza lipsei mijloacelor de traiu strict necesare, Statul a trebuit să le vină în ajutor destinându-le locuri de cultură şi de livezi, ceeace n'a prezintat niciun inconvenient, dat fiind că procentul de împădurire în Slovacia este de $49 \%$, iar în Rusia subcarpatică de 49\%.

Suprafețele păduroase de pe lângă frontiera polono-cehoslovacă, cari au suferit din cauza răsboiului, au trebuit ca să fie exploatate, pentru a se înpedica propagarea insectelor vătămătoare cari, în timpul răsboiului, au găsit un mediu prielnic de desvoltare. 
Pădurile Statului, cari în Slavonia reprezintă un procent de aproape 19\%, iar în Rusia subcarpatică de $55 \%$, din suprafaţa totală a pădurilor, sunt administrate de către Direcţiunea generală a domeniilor şi pădurilor Statului.

Cantitatea de material lemnos exploatat din aceste păduri nu atinge pe cea prevăzută în amenajamentele întocmite şi aprobate în timpul Statului ungar, deoarece în Slovacia s'a tăiat $717.000 \mathrm{~m} 3$ adică cu $27 \%$ mai puţin, iar în Rusia Subcarpatică numai 523.3330 m3 sau cu $61 \%$ mai puţin decât posibilităţile prevăzute. Aşa fiind, nu numai că nu e vorba de exploatări exagerate, dar administraţia forestieră cehoslovacă, în scopul unei exploatări regulate, este obligată a construi în pădurile rămase până acum inaccesibile mijloace de transport costisitoare.

In programul de investiţiuni întocmit de Direcţia generală pentru deceniul următor s'a prevăzut suma de 162 milioane coroane cehe (810 milioane lei), în care scop a intrat în tratative cu mai multe grupuri financiare din ţară şi străinătate pentru procurarea capitalului necesar. Principiul de observat este, ca exploatarea tuturor pădurilor Statului să se facă în regie şi ca vânzarea materialului lemnos rezultat să se efectueze pe o serie de mai mulţi ani, pentru ca cumpărătorul lui să se poată decide, ca să construiască stabilimentele industriale necesare.

\section{Expozeul forestier al delegațiunei române}

\section{Suprafaţa.}

Suprafața totală a pădurilor revenite României în urma Tratatului dela Trianon prin aplicarea liniei de demarcaţiune a lui „Clémenceau", după datele statistice ungurești, este de 3.792.927 ha.

Pentru a se cunoaște adevărata întindere a acestor păduri Ministerul nostru de Agricultură şi de Domenii, prin Casa Pădurilor, a luat măsurile necesare pentru a se întocmi o nouă statistică forestieră.

Statistica pădurilor aparținând Statului fiind publicată în zilele acestea, o depunem odată cu acest memoriu. Aceia referitoare la pădurile particulare şi la celelalte naturi de proprietari va apărea cel mult până la sfârşitul acestui an, când o vom prezintă de asemenea Comisiunei. Statul actualmente posedă în Ardeal o suprafață păduroasă de . . . . . . . . . . 619.796 ha. dintre cari pădurile propriu zise acoper o întindere de . . . . . . . 564.823 ,,

Iar poenile şi golurile de munte . .54.973,,

Suprafaţa de 564.823 ha de păduri ce aparțin Statului, se repartizează la rândul său astfel:

Pădurile de reşinoase ocupă . . . 150.843 ,

$$
\begin{aligned}
& \text { " , fag , . . 307.439, } \\
& \text {, , diferite specii de stejar 88.235, } \\
& \text { " , plop, salcie, teiu, } \\
& \text { carpen, salcâm etc.. . } 18.306 \text {, } \\
& \text { Total . . . } 564.823 \text { ha. }
\end{aligned}
$$

Până în 1922 s'a exploatat conform dispozițiunilor amenajamentelor în vigoare o întindere de . . . . . . . . . . . 89.260 ha, astfel că mai rămâne de tăiat încă 475.563 ,

$$
\text { Total . . . } 564.823 \text { ha. }
$$

\section{Ce prevăd legile ungare relativ la amenajarea şi exploatarea pădurilor?}

Potrivit art. 17 din legea ungară No. XXXI din anul 1879 pădurile Statului, ale comunelor, ale bisericilor, ale corporațiunilor, ale juridicţiunilor şi fundaţiunilor publice şi private, ale fidei-comiselor, ale conposesoratelor, ale celor aparţinând societăților anonime pentru exploatări miniere, precum şi pentru alte industrii, nu pot fi exploatate decât pe baza unui amenajament având de scop asigurarea regenerărei pădurilor şi continuitatea exploatărei, adică realizarea „raportului susţinut”.

Pentru toate aceste păduri exploatarea este condiționată, prin urmare, de existența unui amenajament aprobat de către instanţele superioare.

In ce priveşte însă pădurile particulare, excepție făcând de aşa zisele păduri de protecţie, 
de cele situate pe nisipuri mișcătoare şi în fine de cele aflătoare pe un teren impropriu pentru orice alt soiu de cultură decât cea forestieră, ele nu sunt supuse nici unei restricţiuni, astfel că pot fi exploatate, ori cât de mare ar fi întinderea anuală; ele se pot chiar defrişa.

Iar în conformitate cu art. 7 din legea din 1879 păşunatul nu este oprit decât în pădurile de protecţie, precum şi în acelea situate pe nisipuri mișcătoare, dar numai în timpul când acest pășunat poate să ocazioneze pagube.

\section{Restricții aduse exploatărei pădurilor din ținuturile cari făceau parte din Ungaria în anul 1918.}

In timpul răsboiului mondial din 1914-1918, în vederea extensiunei ce luase exploatarea pădurilor particulare, de reşinoase în special, în disproporţie cu mijloacele de cari dispuneau proprietarii respectivi spre a le putea reîmpăduri la timp, pentru a căror exploatare intensivă o mulţime de fabrici mari de cherestea se înfiinţase, guvernul ungar a emis ordonanța No. 3296 din 1918, potrivit căreia nici o pădure nu putea să se exploateze fără o autorizație prealabilă a serviciului silvic respectiv, care, fixa suprafața anuală de tăiat ținând socoteală numai de posibilitatea de a se putea reîmpăduri întinderile exploatate, iar nici de cum de cererile exagerate ale proprietarilor fabricilor în chestiune.

\section{Măsurile luate de guvernul român.}

Indată ce Transilvania, Banatul, Crișana şi Maramureșul deveniră provincii românești, guvernul nostru a continuat să aplice strict dispoziţiile ordonanţei No. 3296 din 1918 şi anume până în anul 1923, când s'a extins pe întreg teritoriul României aplicarea codului silvic din vechiul Regat, promulgat la 8 Aprilie 1910 şi modificat prin legea din 16 Septembrie 1920.

\section{Dispoziţiile principale ale codului silvie român.}

In baza art. 1 ai acestui cod sunt supuse regimului silvic : pădurile Statului, ale domeniilor Coroanei, ale comunelor, ale fundațiilor publi- ce şi private, precum şi ale tuturor persoanelor juridice (alin. a şi b,); acelea pe cari Statul şi instituțiile prevăzute la alin. a, şi b, le posedă în indiviziune între ele, sau cu alt proprietar particular (alin. c, ); pădurile moșnenilor sau răzeșilor stăpânite în devălmăşie (alin. d,); cele ale proprietarilor particulari situate pe crestele şi versanţii munţilor şi colinelor (alin. e,); pădurile de protecţie (alin. f,); pădurile sau porţiunile de păduri a căror menținere este necesară pentru protejarea malurilor în contra roaderei de către apele curgătoare şi acelea cari asigură cursul regulat al râurilor şi conservarea isvoarelor (alin, g,); pădurile necesare apărărei teritoriului țărei (alin. h,) şi în fine pădurile particularilor neintrând în nici una din prevederile de mai sus, dar pentru cari proprietarii ar fi cerut ca ele să fie supuse regimului silvic.

Potrivit art. 2 din acelaş cod, nici o pădure supusă regimului silvic nu poate să fie exploatată decât pe baza unui amenajament sau al unui regulament de exploatare aprobat prin decret Regal, iar în timpul din urmă prin deciziune ministerială.

Amenajarea pădurilor având de scop conservarea şi regenerarea lor, producția lemnului de lucru şi de construcțiuni, precum şi realizarea raportului susținut, este obligatorie pentru pădurile indicate la art. 1, alin. a, b, c, şi d, pe câtă vreme regulamentul de exploatare, care urmărește conservarea pădurilor şi regenerarea lor cu specii prețioase proprii regiunei respective, este obligator numai pentru pădurile proprietarilor particulari supuse regimului silvic. El pot totuşi, dacă vor, să-şi amenajeze pădurile.

\section{Cauțiunea pentru asigurarea împădurirei.}

Prin orice amenajament sau regulament de exploatare privitor la pădurile particulare trebuie să se prevadă suma ce proprietarii sau exploatatorii sunt datori a o consemna în comptul Ministerului de Agricultură, drept garanție că reîmpădurirea se va face de fapt.

Această sumă prin codul silvic din 1910 a fost fixată la 100 lei de hectar, iar prin legea modificatoare dela 1920 s'a prevăzut, că ea 
poate fi majorată, astfel că astăzi, când unei păduri se aplică codrul plin cu tăeri rase, se fixează de ordinar la 3000 şi 4000 lei de hectar, în afară de obligația pentru proprietar de a-şi crea pepinierele necesare.

\section{Pedepsele cari se aplică contravenienților.}

Când tăierea pădurilor supuse regimului silvic se face fără amenajament sau regulament de exploatare, ori contra dispoziţiilor ce acestea cuprind, Ministerul are dreptul de a interzice tăierea, precum şi de a supune pe contravenient la o amendă care variază dela 3 -5000 lei de hectar.

\section{Interzicerea defrişărei.}

Potrivit art. 12 din legea modificătoare din 1920 a codului silvic din 1910 defrişarea pădurilor, fie ele supuse ori nesupuse regimului silvic, este cu desăvârşire interzisă. Se face însă excepţie pentru pădurile situate în regiunea de munte în limitele şi condiţiile legei speciale de expropriere, precum şi pentru creiarea de păşuni comunale. Defrişarea după codul silvic poate fi permisă numai în anumite cazuri şi anume: dacă proprietarul se obligă să planteze în locul pădurii arbori fructiferi ; când pădurea este situată în câmpie şi are o întindere mâi mică de 25 ha.; când se dă în schimbul unei porţiuni înfundate (enclave) o suprafaţă echivalentă lângă perimetrul pădurei, precum şi atunci când întinderea defrişată este compensată prin împădurirea prealabilă a unei suprafeţe egale, iar plantele în vârstă de cel puţin 3 ani prezintă toate garanţiile că împădurirea a reuşit pe deplin.

\section{Dispoziţiunile codului silvic român relative la pășunat.}

Păşunatul în pădurile supuse regimului silvic, despre care se face menţiune la art. 1 alin. a, b, şi c, din c. s. este cu totul interzis. In pădurile din lunca Dunărei sau alte cursuri de apă el este permis, iar în cele particulare (alin. e) numai în cazurile următoare:
In pădurile tratate în codru cu tăeri rase sau cu tăeri de regenerare progresive, dacă aceste păduri sunt în vârstă mai mare de 30 de ani;

In pădurile cărora li se aplică crângul compus sau crângul simplu, dacă vârsta lor a trecut de 15 ani;

In pădurile de baltă după dispoziţiile prevăzute la art. 15 alin. a şi b;

Păşunatul este cu desăvârşire oprit:

a) In pădurile tratate în codru grădinărit, în care durata rotaţiunei este mai mică de 15 ani;

b) In pădurile surpate sau supuse surpăturilor prin faptul păsunatului;

c) In pădurile de protecţie.

In pădurile nesupuse regimului silvic păşunatul este permis, numai dacă vârsta lor este mai mare de 10 ani, iar în pădurile de baltă numai dela 3 ani în sus.

\section{Reforma agrară.}

Pentru a se săvârși o operă de dreptate socială încredinţându-se pământul cultivabil celor cari îi muncesc cu adevărat, prin Constituţia din anul 1919 şi prin legea pentru reforma agrară din Transilvania, Banat, Crișana şi Maramureș s'a dispus, ca să se exproprieze, în parte sau în total, pentru cauză de utilitate publică pământurile de cultură din proprietățile rurale cu o suprafață de la 50 - 500 jugăre cadastrale.

Prin art. 12 al acestei din urmă legi s'a prevăzut, că în regiunile unde cererea de pământuri expropriabile este importantă şi mai ales pentru a se completa minimum de 7 jug. cad. de fiecare locuitor având dreptul a fi împroprietărit, se va putea, cu avizul serviciului silvic respectiv, expropria chiar o parte din pădurile existente.

Terenurile des inundabile, cele mlăştinoase, neproductive, terenurile supuse surpărilor, nisipurile, precum şi albiele râurilor, pentru a fi ameliorate sau plantate de către comună sau de Stat, vor putea fi expropriate în total.

Privitor la crearea de păşuni comunale, iată ce se stipulează prin art. 24 :

„Când interesul economic al populaţiei cere, $\mathrm{cu}$ avizul serviciului silvic şi cu aprobarea Co- 
mitetului agrar, se va putea expropria şi parte din păduri, dar numai dacă terenul este propriu pentru păşunat".

Trebue să menţionăm, că în acest caz nu se lasă terenurile goale, ci se creiază păşuni împădurite (près bois), pentru formarea cărora se menţin în picioare buchete de arbori, după cum se practică în Elveţia, în Franţa (în munţii Juna), precum şi în alte ţări.

Afară de aceasta nici o defrişare de păduri nu se poate face fără o cercetare locală a şefului de ocol respectiv şi fără avizul favorabil al consiliului tehnic de pe lângă Casa Pădurilor, care nu se dă, decât dacă panta nu este repede, iar terenul nu este supus surpăturilor.

Pentru a da o noţiune asupra spiritului care a dominat şi asupra precauţiunilor luate ca să nu se aprobe defrişările de păduri decât în cazuri cu totul escepţionale, reproducem aici un pasagiu din instrucţiunile trimise în această privinţă de Ministerul Agriculturei şi Domeniilor inginerilor agricoli însărcinaţi cu aplicarea legei de reformă agrară în România:

„Propunerile privitoare la exproprierile pădurilor vor fi făcute cu cea mai mare scrupulozitate şi numai în cazuri de absolută necesitate, adică când nu s'ar găsi nici un mijloc de a satisface necesitatea păşunatului ; ele vor fi făcute excepţional şi numai acolo unde, schimbându-se destinația pădurii, adică transformând'o în păşune nu se atinge nici un interes general şi când prin o asemenea despădurire nu se dă loc la surparea terenurilor cu o pantă repede, la formarea de eroziuni, ravene, ţorenţi etc" .

\section{Măsuri luate pentru crearea de noui păduri şi asigu- rarea regenerării celor existente.}

In cursul anului 1923/924 s'a cules o cantitate de 600 kg sămânță de molid şi s'a repopulat în pădurile Statului din Transilvania, Banat etc., o întindere de 1290 ha, iar în cele administrate de Stat 1300 ha, în total deci 2590 ha.

S'a cules în acelaş timp semințe de specii foioase o cantitate de $159 \mathrm{hl}$ şi s'a semănat o suprafață de 17 ha în pepinierile din pădurile Statului şi 11 ha în cele administrate de Stat, în total deci 28 hectare.

S'a cheltuit cu acest prilej: 4.255 .000 lei.

In cursul anului 1924/925:

S'a reîmpădurit 2726 ha.

S'a semănat în pepiniere 41 ha.

S'a cules seminţe de foioase 2988 hectolitre.

S'a cules seminţe de molid $13770 \mathrm{~kg}$.

Cheltuiala a fost de 5.345.240 lei.

In cursul anului 1925:

După devizele întocmite şi aprobate:

S'a proectat a se împăduri anul acesta 5.642 ha, costul lor fiind de 6.000.000 lei din cele 13 milioane lei prevăzute pentru împăduriri în întreaga ţară.

In afară de aceasta, diferitele direcţiuni regionale silvice s'au aprovizionat din timp cu sămânţa de salcâm, de care au nevoie pentru împădurirea unei suprafețe cât mai mare din terenurile neproductive;

$\mathrm{Nu}$ numai atât, direcţiunea regională din Orşova a adunat în plus $700 \mathrm{~kg}$, iar cea din Buzău 500 kg semânţă de salcâm, spre a fi distribuită gratuit, sau pe preţul de cost, particularilor. Această din urmă direcțiune a mai recoltat afară de aceasta şi 13 vagoane de ghindă, iar aceea din Chişinău 8 vagoane, pentru a servi împăduririlor proectate a se face anul acesta.

Casa Pădurilor pentru a stimula cât mai mult acţiunea de împădurire în România, prin ordinul său Nr. 15652/923 a luat măsuri ca pădurarii, în număr de 5446 în întreaga ţară, să înfiinţeze mici pepiniere, să semene în regiunea de câmpie şi cea de coline seminţe de foioase, iar în cea de munte seminţe de reşinoase, în scopul de a se produce şi de a se planta de fiecare pădurar o cantitate de cel puţin 10.000 pueţi. Cheltuelile necesare, ca şi costul seminţei, sunt în sarcina Casei Pădurilor. Pădurarii cari se disting printr'un deosebit zel, primesc gratificaţii, pe când cei neglijenţi sunt amendaţi sau chiar concediaţi din serviciu.

Şefii de ocoale respectivi sunt obligaţi de a le da toate instrucţiunile necesare pentru a şti cum se lucrează în pepiniere, cum se face ambalajul şi se transportă pueţii, cum se plantează etc.

Superiorii lor sunt făcuţi responsabili, dacă n'au executat un control efectiv, pentru a-şi în- 
deplini fiecare gardian îndatorirea ce i s'a pus.

$\mathrm{Cu}$ chipul acesta se va putea planta regulat, în fiecare an, peste 50 milioane de pueţi.

\section{Alte iniţiative spre a se promova împăduririle.}

Pentru a se accelera şi da cât mai mare desvoltare lucrărilor de împădurirea terenurilor neproductive, în special, s'a format în Arad un comitet compus din directorul silvic din localitate, din prefecții județelor respective, din consilierii agricoli şi din şefii de ocoale silvice, în scopul de a se înfiinţa pepiniere, de a se elibera gratuit pueţi populaţiei şi de a se aduce în stare de producţiune, prin împădurire, toate terenurile neproductive din cuprinsul direcţiunei regionale cu sediul în Arad.

Afară de aceasta Direcţiunea generală a apelor, de curând înfiinţată în Ministerul Lucrărilor Publice, a cerut şi a obţinut dela Casa Pădurilor 500000 de pueţi de salcâm etc. spre a se împăduri terenurile neproductive din perimetrele şi basinele de recepţie ale ravenelor şi torenţilor.

Pentru a se satisface numeroasele cereri ale particularilor de a li se acorda gratuit, sau pe preţul de cost, pueţii destinaţi la împădurirea terenurilor sterile, Casa Pădurilor în ultimul timp a eliberat aproape 2 milioane de pueţi, de salcâm mai ales.

\section{0 experienţă făcută.}

O lungă experienţă a dovedit, că metoadele de constrângere pentru conservarea şi exploatarea raţională a pădurilor particulare aproape nicăeri n'au dat rezultate bune. Astfel, la congresele internaţionale de agricultură şi de silvicultură ţinute la Madrid în 1911, la Paris şi Gand în anul 1913, pentru a nu cita decât congresele cele mai apropiate de răsboiul mondial din 1914, privitor la pădurile particularilor s'a preconizat întrebuinţarea de soluţii liberale.

\section{Sărbătoarea sădirei arborilor.}

In această ordine de idei Casa Pădurilor, pentru a răspândi în straturile cele mai largi ale naţiunei cultul arborelui, a organizat, în înțelegere cu Ministerul de Instrucţiune Publică, sărbătoarea sădirei arborelui, care constă din punerea la dispoziţia corpului didactic în fiecare primăvară, pueții destinaţi a fi plantaţi de către şcolarii lor, - după instrucţiunile ce li se dau de către personalul silvic, - în prezenţa populaţiei rurale şi a autorităţilor administrative şi militare locale.

Efectele unor astfel de măsuri, judecând după rezultatele de până acum, nu vor putea fi decât binefăcătoare.

\section{Măsuri luate pentru a preveni contravenţiele la clauza reîmpăduririlor.}

Pentru a preveni contravenţiile relative la obligaţia de a se reîmpăduri porţiunile exploatate conform prevederilor amenajamentelor şi regulamentelor de exploatare, Casa Pădurilor a luat măsuri, ca pe viitor să nu se mai acorde noui autorizaţiuni de tăiere proprietarilor de păduri particulare supuse regimului silvic, dacă într'un termen de 4 ani, socotiţi dela ultima tăere a parchetelor sau a parcelelor, acestea nu se vor fi regenerat complect.

\section{Personalul silvic de naţionalitate ungară.}

Spre a dispune de cât mai multe elemente în stare de a contribui cu folos la opera de restaurare şi îmbunătăţire a pădurilor din Transilvania, Banat etc, Casa Pădurilor a menţinut în serviciu pe toţi funcţionarii silvici de naţionalitate ungară, cari au voit să rămână în ţară. Numărul acestor funcţionari este astăzi următorul:

112 ingineri silvici de diferite grade

4 conductori silvici

115 brigadieri ,

355 pădurari

37 funcţionari administrativi.

Total 623 persoane

Tuturor acestor funcționari guvernul român le-a asigurat dreptul la pensie, fără a fi obligați să verse Casieriei generale a pensiilor suma corespunzătoare timpului servit sub administrația ungară. 


\section{Concluzie.}

Din această expunere sumară rezultă, într'un mod evident, că guvernul român este bine pătruns de importanța, din toate punctele de vedere, a pădurilor din țara noastră şi că face toate sforţările posibile, toate sacrificiile financiare, destul de grele în aceste timpuri de criză monetară şi că el este ferm hotărât de a continua, din ce în ce mai intens, acţiunea de împădurire şi de ameliorare a pădurilor noastre, cari reprezintă una din principalele bogăţii naţionale ale României.

Preşedintele, după citirea expozeului forestier român, rosti următoarele cuvinte :

„, Sunt sigur, că interpretez sentimentele întregii Comisiuni mulțumind foarte mult delegaţiunei României pentru interesantul său expozeu”.

Iar delegatul Ungariei declară :

„Constat cu plăcere, că expozeul delegaţiunei române dă cele mai compacte asigurări asupra împăduririi in Transilvania şi sper că legile sale vor fi riguros aplicate în mica zonă ce interesează Ungaria”.

Este vorba de zona formată de basinele râurilor, cari se varsă în Tisa, aflătoare la o distanţă cam de $100 \mathrm{~km}$ de la acest râu şi care acoperă suprafaţa de circa $63.000 \mathrm{~km}^{2}$.

După o lungă discuţiune, la care au luat parte reprezentanţii delegaţiunilor, asupra chestiunii împădurirei şi despădurirei, delegatul Ungariei afirmă, că are toată încrederea în legile forestiere ale ţărilor succesorale şi că nu se îndoieşte, aceasta fiind şi în interesul propriu al acestor State, că se va lua măsuri energice pentru împădurirea terenurilor degradate şi roagă în special guvernul român să dea toată atenţiunea exploatărilor pădurilor din basinele rîurilor Mureş şi Someş, căci aceşti afluenţi ai Tisei, cari transportă mari cantităţi de aluviuni, au o mare influență asupra regimului acestui din urmă râu. Atrage asemenea atenţiunea asupra terenurilor din apropierea comunei Pecica, inclusiv pădurea de pe lângă Mureş, de oarece în timpul viiturilor mari de apă prin stratul de humus şi pătura moartă din această pădure se absoarbe şi se reţine o însemnată cantitate de apă.

Preşedintele luând cuvântul fu de părere, că cererile Ungariei sunt rezonabile şi aşa fiind crede, că ţările respective vor lua măsuri ca ele să fie realizate, aceasta intrând în prevederile Tratatului de pace dela Trianon.

$\mathrm{Cu}$ această ocaziune delegatul României a depus :

Un exemplar din codicele nostru silvic din $1910 \mathrm{cu}$ modificările sale din 1920, inclusiv legea din 1923 prin care se extinde asupra întregului teritoriu al României aplicarea codului silvic din vechiul Regat.

Un exemplar din statistica pădurilor Statului şi

Numărul de pe 1920 din „Revue générale des Sciences" care apare la Paris, consacrat în întregime scriitorilor români, în care se află şi un articol al profesorului Petre Antonescu asupra pădurilor.

Duminecă, 5 Aprilie, membrii Comisiunii au fost invitați de primarul oraşului Merano la o ascensiune cu funicularul în muntele din dreptul localității „Liana”, unde li s'a oferit o gustare la restaurantul aflător la altitudinea de 1500 m, în prejurul căruia se afla un strat gros de zăpadă, pe câtă vreme în vale înfloreau portocalul, magnolia etc.

Luni seara, 6 Aprilie, președintele, d-1 Carlo Rosetti, a dat în onoarea Comisiunii un banchet urmat de un bal, la care au asistat 130 notabilităţi, domni şi doamne, din oraşul Merano.

Marţi, 7 Aprilie, când s'au terminat şedinţele, d-1 inginer inspector general I. Vardala intr'o cuvântare substanţială spuse, că este foarte fericit de faptul, că colegii săi i-au încredinţai misiunea foarte plăcută de a exprima preşedintelui cele mai vii multumiri ale lor, pentru modul amabil cu care a condus desbaterile şi pentru spiritul amical ce, graţie lui, domneşte şi se desvoltă continuu în sânul Comisiunii.

El îl roagă, afară de aceasta, de a binevoi să se facă interpretul pe lângă reprezentantul guvernului Italian şi al oraşului Merano, a sentimentelor de gratitudine a intregii Comisiuni pentru primirea cordială şi entuziasmul oferit şi termină formulând urările sale cele mai sin- 
cere pentru fericirea Italiei.

Iată rezoluţiunea adoptată în chestiunea ,despăduririi şi împăduririi”:

\section{COMISIUNEA}

examinând chestiunea despăduririi şi împăduririi, astfel după cum se prevede prin art. 293 din Tratatul de la Trianon şi ascultând expozeurile tuturor delegațiunilor,

constatând că această chestiune formează obiectul grijilor celor mai sârguincioase a tuturor guvernelor reprezentate în Comisiune,

şi că asigurările date în această privinţă de către oarecari delegațiuni sunt de natură a potoli îngrijorările ce ar fi putut avea alte delegaţiuni, precum şi că cererile prezintate nu par a depăşi limitele rezonabile, ţinând afară de aceasta socoteală de interesele speciale şi de drepturile fiecărui Stat și că ele intră în cadrul atribuțiunilor încredințate Comisiunii,

\section{DECIDE:}

$\left.1^{\circ}\right)$ Ca diferitele delegaţiuni să aducă la cunoștința guvernelor lor punctul de vedere în care întreaga chestiune a fost privită de Comisiune şi care se desprinde din discuțiunea care a avut loc în şedinţele dela 4 şi 6 Aprilie, precum şi cadrul general al cererilor prezintate de către delegaţiunea ungară.

$2^{\circ}$ ) De a ruga delegaţiunile Ungariei şi a Regatului Sârbilor, Croaţilor şi Slovenilor de a supune Comisiunii, la viitoarea sesiune, $\hat{\imath}$ amănunt informațiunile şi datele periodice ce ar dori să aibă.

Ea îşi rezervă dreptul de a lua în această chestiune o rezoluție definitivă în viitoarea sesiune. 